\section{(CB monursan LAW REVIEW}

\author{
Volume 3 No 1, December 2020 \\ P-ISSN: 2655-2353, E-ISSN: 2655-6545
}

Article Info:

Received : 04-10-2020

Revised : 11-11-2020

Accepted : 15-12-2020

\title{
Environmental Justice in Intra- Generations: an Overview of Aristotle's Distributive Justice to Coal Mining
}

Yovi Cajapa Endyka ${ }^{1 *}$, Muhamad Muhdar', Abdul Kadir Sabaruddin ${ }^{3}$

1,2,3 Faculty of Law, Universitas Mulawarman, Indonesia

*Corresponding: yovicajapaendyka@gmail.com

\begin{abstract}
Indonesia is a country with abundant natural resources, ranging from sand, tin, copper, coal, iron ore to gold. Therefore, the State should provide wise and sustainable management of natural resources to ensure environmental justice. This study will examine how Aristotle's distributive justice can sharpen the concept of justice for coal mining management. This study will focus on environmental justice in intragenerational terms in terms of Aristotle's distributive justice to coal mining. Protection of access (conservation of access) reflects the allocation of rights and access to natural resources balance between different generations and fellow members of the current generation. Thus, access to protection provides fair and non-discriminatory rights for every citizen of the current generation to use environmental resources. However, in using these resources, each member of the current generation has an obligation (equitable duties) to ensure that his actions will not reduce future generations' access to these resources. The state through mining or environmental policies has not provided justice for the community, where the community are exposed to
\end{abstract}

more risks such as social injustice, environmental and health harm from coal mining activities than receiving the benefits.

Keywords: coal; mining; sustainable development; distributive justice; environmental justice.

\section{Introduction}

Environmental law is the field of law dealing with the preservation and protection of the environment, including preventive measures such as the requirements of environmental-impact statements, as well as measures to assign liability and provide cleanup for incidents that harm the environment. ${ }^{1}$ Environmental justice is an essential matter for every living being that depends on natural resources. Indonesia is a country with abundant natural resources, from sand, tin, copper, brass, iron ore to gold. ${ }^{2}$ To carry out the management and utilization of this abundant natural resource, the State requires much capital. Therefore it requires the involvement of investors or companies that participate in investing and managing this natural wealth.

1 Garner, B. A. (2009). Black Law Dictionary. 9th edition. U.S.A. Thompson West Group. p. 642.

2 Awaliyah, S. (2014). Kontrak Karya Dan Perjanjian Karya Pengusahaan Pertambangan Batubara (KK/PKP2B). Jurnal Pendidikan Pancasila dan Kewarganegaraan. Vol. 27. (2).p. 111. 
One of the most attractive business fields for the results. Third, following the principles of investors is the mining and natural resource Article 33 paragraph (4) of the 1945 extraction sectors. These sectors are still the Constitution, namely efficiency with justice, mainstay for the acceleration of Indonesia's the economy needs to be run by using a fair economic development. ${ }^{3}$

Indonesia is rich in natural resources and this phrase is often embedded in various text discourses and political and legal narratives. 4 The regulatory factor is an essential element because it becomes the guide for the State as the party that controls Natural Resources. ${ }^{5}$ Normatively, the legal politics of natural resource management in Indonesia have been stipulated in the Republic of Indonesia's Constitution. 1945 Constitution Amendment ${ }^{6}$ as being carried out on Article 33 (4) of the 1945 Constitution "The organization of the national economy shall be conducted based on economic democracy upholding the principles of togetherness, efficiency with justice, continuity, environmental perspective, selfsufficiency, and keeping a balance in the progress and unity of the national economy", it is related to liberalization in the natural resource management sector. Natural resource management must contain seven constitutional features: First, the economy aims to achieve shared prosperity for all people.

Second, people's participation in the ownership, production process and enjoying

3 Lestari, D. (2016). Dampak Investasi Sektor Pertambangan Terhadap Pertumbuhan Ekonomi Dan Tenaga Kerja. Jurnal Ekonomi. Manajemen dan Akuntansi. Vol. 16. (3).p 176.

4 Muhdar, M. (2020). Rekonstruksi Basis Perhitungan Kerugian Negara dalam Peristiwa Tindak Pidana Korupsi pada Sektor Sumber Daya Alam. Jurnal de Jure Vol 12 (1) April. p. 39.

5 Muhdar, M. et al. (2015). Implikasi Hukum Terhadap Praktik Pinjam Pakai Kawasan Hutan untuk Kegiatan Pertambangan Batubara. Halrev. Vol 1(3).p. 433.

6 Qurbani, I. D. (2012). Politik Hukum Pengelolaan Minyak dan Gas Bumi di Indonesia. Jurnal Arena Hukum Vol. 6 (2). August. p. 79-154. market mechanism based on healthy competition and the role and authority of the State for intervention in the event of a market failure. Fourth, the role of the State must be guaranteed as mandated by the 1945 Constitution, especially in terms of national economic planning, in shaping and enforcing the implementation of laws and in implementing community service and empowerment programs, tax exemptions, providing subsidies and others. 7

Fifth. State-owned enterprises (BUMN) as one of the pillars of economic activity, controls important production branches and those that control the lives of many people. Sixth, cooperatives as the pillars of the economy must be realized in the spirit of togetherness with State-owned enterprises and the private sector and people's economic enterprises. Seventh. The national economy must manifest equal partnerships between cooperatives, state-owned enterprises and the private sector. 8

Equal partnerships can be made for parties conducting a single transaction. In contract theory, it describes the agreement of one actor to take any action that has economic value to another party. The consequences of reciprocal action or payment. So in a partnership, there must be reciprocal economic action. These characteristics must be translated into a series of regulations concerning mineral and coal mining. 9 For expositional simplicity and to maintain consistency with the subsequent empirical work that employs the Ecological Footprint to measure environmental

7 Tjakrawerdaja, S. (2008). Menunggu UU Induk

Mengenai Perekonomian Nasional. Reform Review. Volume 2 (1) April-June. p. 40

8 Ibid.p. 40.

9 Yustika, A. E. (2013). Ekonomi Kelembagaan Paradigma. Teori. dan Kebijakan. Jakarta: Erlangga. 
utilization. 10 The utilization of natural Kutai Kartanegara, they have to move their resources should provide justice for every residence or be marginalized due to mining living being, both the present and future activities. The environment that directly generations.

Economic development through natural resources should prioritize sustainable development. Sustainable development can be derived into several core elements: the principle of integration, which asks for guarantees that environmental considerations will be integrated into plans, policies, and programs related to economy and development, and that meeting development needs must take into account the objectives of environmental protection, the principle of sustainable use, which is reflected in the exploitation of natural resources in a sustainable, prudent, rational, wise, and appropriate manner, the principle of intragenerational justice, which is shown through the equitable use of natural resources (fair use of natural resources), where the use of natural resources by one country must still pay attention to the needs of other countries and the principle of justice between generations, which can be seen from the need to protect natural resources for the benefit of creating future ones. ${ }^{11}$

The distributive justice is related to the equitable distribution of resources and risks that apply at the regional, national and international levels. In fact, in some cases, such as in Mulawarman Village, 12 District

10 Chambers, D. \& Guo, J-T. (2009). Natural Resources and Economic Growth: Some Theory and Evidence. Annals of Economics and Finance November. p. 4.

11 Wibisana, A. G. (2017). Keadilan Dalam Satu (Intra) Generasi: Sebuah Pengantar Berdasarkan Taksonomi Keadilan Lingkungan. Mimbar Hukum Vol. 29. (2). June. p. 292-307. affects people's lives, such as rivers and plants cannot be enjoyed again as it should have been before mining activities took place. The granting of mining business permits to entrepreneurs based on the interests of forest utilization as an economic interest becomes a priority so that the rights of the communities around the mine are indirectly injured or marginalized by the economic interests proclaimed by the government.

Coal mining and community rights in one (intra) generation is a big question, coal mining can provide access to accommodate economic interests and realize distributive justice that give a proportional equality to everyone what is their right and obligation according to their abilities and achievements. The distribution of risk in coal mining activities still seems unfair on what has been done by coal mining operators to the benefits and environmental damage that are shared with the community in intra generation. Remarkably, the state should be can provide justice to the community and coal mining operator towards risk distribution on coal mining.

\section{Discussion and Analysis}

\subsection{Aristotle's Distributive Justice in Intra-} Generation

Theories that examine the problem of justice in-depth have been carried out since ancient Greece. ${ }^{13}$ Natural Law theories from Socrates to Francois Geny still maintain justice as the crown of law. Natural Law

12 In the case of Mulawarman villagers, the loss of food production has become the main problem that makes them fail to maintain food self- ${ }^{13}$ Nasution, B. J. (2014). Kajian Filosofis Tentang sufficiency. As a result, the villagers have lost Konsep Keadilan dari Pemikiran Klasik Sampai their independence and turned to the government Pemikiran Modern. Yustisia Vol. 3 (2) May in order to qualify for social welfare, not to August.p.118-130. 
Theory prioritizes "the search for justice, 14 gives everyone what is their right and various kinds of theories regarding to justice obligation according to their abilities and and society, theories concern rights and achievements. ${ }^{17}$

freedoms, income and prosperity. Among those theories can be called: Aristotle's theory of justice in his book Nicomachean ethics and John Rawl's theory of social justice in his book a theory of justice and Hans Kelsen's theory of law and justice in his book general theory of law and State. In the study of philosophy, several theories of justice have been emphasized by several philosophers based on equality. Some of them are Aristotle. Thomas Aquinas and John Rawls. Aristotle provides the concept of justice through equal status, equality of rights and obligations proportionally through distributive justice which Thomas Aquinas later developed. Furthermore. John Rawls also stated that there must be something called the original position in the concept of justice which places everyone equally in position and status to have equal rights to fundamental freedoms. 15

Aristotle's views on justice can be found in his work on Nichomachean ethics, politics and rhetoric. Seen explicitly in the book Nicomachean Ethics, the book is entirely devoted to justice based on Aristotle's philosophy of law "because the law can only be established with justice."16 This view of justice is a granting of equal but not equal rights. Aristotle distinguished his equal rights according to proportional rights. In terms of equality of human rights as an equal creature. This is what can be understood by every citizen and everyone is equal before the law. Proportional equality

${ }^{14}$ Friedrich, C. J. (2004). Filsafat Hukum Perspektif Historis. Bandung: Nuansa dan Nusamedia. p. 24. 15 Adlhiyati, Z. \& Achmad. (2019). Melacak Keadilan dalam Regulasi Poligami: Kajian Filsafat Keadilan Aristoteles. Thomas Aquinas. dan John Rawls. Jurnal Hukum, Vol. 2 (2). p. 409-431.

Aristotle's view on justice is divided into "distributive" justice and "commutative" justice. Distributive justice is justice that gives each person a portion according to his / her achievement. Commutative justice provides as much to everyone without differentiating their performance in this case related to the role of exchanging goods and services. 18 Through this division of justice. Aristotle gets much debate on the thoughts put forward.

Distributive justice according to Aristotle, focuses on distribution, honorarium, wealth and other goods that can be found in society. Putting aside the mathematical "proof." it is clear that what Aristotle had in mind was the distribution of wealth and other valuables based on prevailing values among the citizens. ${ }^{19} \mathrm{~A}$ fair distribution may be a distribution following the value of goodness, namely its value for society. Aristotle's doctrines not only laid the foundations for legal theory but also western philosophy in general. Aristotle's contribution to the philosophy of law is his formulation of the question of justice which distinguishes between "distributive" justice and "corrective" or "remedial" justice, which is the basis for all theoretical discussion of the subject matter. Distributive justice refers to distributing goods and services to everyone according to their position in society and equal treatment of equality before the law.20

One key problem with contemporary liberal theories of justice is that recognition

17 Amin, S. (2019). Keadilan Dalam Perspektif Filsafat Hukum Terhadap Masyarakat. El-Afkar Vol. 8 (1). January-June. p. 2.

${ }^{18}$ Friedrich, C. J. Op. Cit. p. 25.

${ }^{19}$ Faiz, P. M. (2009). Teori Keadilan John Rawls. Jurnal Konstitusi. Vol. 6 (1). p. 135.

16 ApeldoornL. J. V. (1996). Pengantar Ilmu Hukum. ${ }^{20}$ Helmi, M. (2015). Konsep Keadilan Dalam Cetakan Ke Dua Puluh Enam. Jakarta: Pradnya Filsafat Hukum dan Filsafat Hukum Islam. Paramita.

Mazahib. Vol. 25. (2) December. p. 133-144. 
and its link to both distribution and to coal mining should be sustainable participation.That recognition is an element development where this has been realized in of justice should be uncontroversial; that it Environmental Protection and Management has been so neglected should be admitted Act 2009 and discussed in several national and addressed. Its articulated and and international meetings. In essence, all of understood as a balance of numerous them are efforts to protect natural resources interlinked elements of distribution, and the environment as one of the recognition, participation and capability. ${ }^{21}$ fundamental problems that underlie Furthermore, any conflict of interest between sustainable development ${ }^{24}$. Intra-generational cool mining operator, state and society in the Justice is justice aimed at those who live in implementation of mining activity. Economic one generation related to the equitable growth, coal mining profit, environment distribution of resources. ${ }^{25}$ Every generation would be point of view from any parties has the right to live well and appropriately in whose impacted by coal mining activity as an a conducive situation where there is no optimization on natural resources or injustice disturbance physically and spiritually. Each issue from the society. The tension between generation should not be burdened by the the repercussions of these injustices versus problems generated by previous the economic benefits of coal mining are generations.26

reflected in the literature from a wide range of countries at virtually all stages on the economic development scale. A universal conflict of power and priorities is evident and is arguably a direct function of contemporary society's use of coal power as a base for the expansion of economic growth. This conflict includes contestation over fundamentals such as water rights and land use. 22

Environmental justice is concerned with the equitable distribution of environmental rights and benefits among people, such as give a rights to operate a coal mining which is cognizance to sustainable development and give a value to society and state. Here, the procedural aspect of public participation in decision-making is 2.2. Realizing Environmental Justice for Coal Mining in Intra-Generation

Based on Dobson's opinion as quoted by Langhelle, distributive justice has a very close relationship with sustainable development for three reasons, namely: first, the environment is a resource that must be distributed relatively; second, justice is functional in creating sustainability; and third, sustainability also requires justice for the environment itself. Langhelle then added a fourth reason, namely that sustainability is also a necessary condition for creating considered a substantive right that is part of 24 Wowor, K. (2017). Penerapan Prinsip distributive justice. ${ }^{23}$ Distributive justice in Berkelanjutan Sebagai Upaya Pencegahan Kerusakan Lingkungan Hidup Dibidang Pertambangan Ditinjau dari UU Nomor 4 Tahun 2009. Agri-Sosioekonomi Unsrat. Vol. 13 (2) July. p.

21 Schlosberg, D. (2007). Defining Environmental 343-354.

Justice Theories, Movements, and Nature. USA: ${ }^{25}$ Nababan, R. K. (2017). Potensi PP KLHS dalam Oxford University Press.

Mengintegrasikan Pembangunan Berkelanjutan

22 Morrice, E. \& Colagiuri, R. (2013). Coal mining, dalam Penyusunan Kebijakan. Rencana. dan/atau social, injustice and health: A universal conflict of Program. Jurnal Hukum Lingkungan Vol. 3 (2). power and priorities. Health \& Place 19. p.74-79 March. p. 125-140.

${ }^{23}$ Setyorini, S. N., Wirdyaningsih. \& Hazna, C. A. ${ }^{26}$ Maryanto. (2018). Membangun Lingkungan (2019). Wakaf Lingkungan Hidup dalam Rangka Yang Berbasis Konsep Berkelanjutan. Jurnal MetaPelaksanaan Pembangunan Berkelanjutan Dan Yuridis Vol.1 (1). p.37-47. 
justice. ${ }^{27}$ The pursuit of justice in law is a Distributive justice calls for a more equitable dynamic process that takes a long time. These allocation of access to and benefits from efforts are often also dominated by forces environmental resources, for benefits of fighting within the political order's general environmental protection and costs of framework to actualize it. ${ }^{28}$ Justice in the environmental protection. Corrective justice ideals of law which is a human struggle has wants a legal instrument that allows those evolved to follow the rhythm of the times who have caused harm to correct and and space, from the past to the present day eliminate the losses it causes. Procedural without stopping. ${ }^{29}$

The Indonesian constitution through Article 33 firmly describe that the state has to protect the whole nation and homeland and to utilize natural resources for the well-being of the people. The whole homeland implies a guarantee to all citizens for legal protection. This covers the protection of individuals in their access to natural resources as well as providing for a safe and healthy environment. In fact, Indonesia constitutes one of only a few countries in the world that incorporate environmental protection and entitlement into their constitutions. 30 Through Environmental Protection and Management Act 2009, the State should be present in providing justice for the management of natural resources, especially from coal mining activities to the surrounding community to provide justice for the present and future generations for a good and proper environment.

Coal mining management should prepare for an Intra-generational justice that can be seen from at least four perspectives, namely environmental justice as distributive. Corrective, procedural and social justice.

${ }^{27}$ Langhelle, O. (2000). Sustainable Development and Social Justice: Expanding the Rawlsian Framework of Global Justice. Environmental Values. Vol. 9 (3).p. 296.

28 Friedrich, C. J. Op. Cit. p. 239.

29 Subhi, A. M. (2001). Filsafat Etika. Jakarta: PT.

Serambi Ilmu Semesta.

30 Muhdar, M., Nasir, M. \& Nurdiana, J. (2020). 31 Wibisana, A. G. (2017). Op. Cit. p 305.

Risk Distribution in Coal Mining: Fighting For 32 Sands. P. (1995). Principles of International Environmental Justice in East Kalimantan. Environmental Law: Frameworks, Standards, and Indonesia. Advances in Social Science. Education and Implementation. Manchester: Manchester Humanities Research. Vol. 499. p. 656-664. justice requires a process that ensures that distribution will be carried out fairly. In general, procedural justice can be realized by recognizing the right to participate in decision-making, the right to information and the right to contest. Meanwhile, social justice is a concept of justice that sees that environmental problems arise from social inequality and poverty. So that alleviating poverty and eliminating conditions of social injustice are integral parts of environmental protection and management efforts. ${ }^{31}$

Sands divides the principles of sustainable development into several legal principles/elements, namely: a) justice between generations, which can be seen from the need to protect natural resources for the benefit of future generations; b) Sustainable use, which is reflected in exploiting natural resources in a sustainable, Prudent, Rational, Wise, and proper manner; c) Intragenerational justice, which is demonstrated through the equitable utilization of natural resources. where the use of natural resources by one country must still pay attention to the needs of other countries; and d) The principle of integration, which calls for guarantees that environmental considerations will be integrated into economic and development policies as well as guarantees that the fulfillment of development needs must take into account the objectives of environmental protection. ${ }^{3233}$ The public interest is rooted in Implementation.
University Press. 
a philosophy known as social contract theory, intra-generational justice can be seen in using the idea "that people collectively agree to the discount rate in the economic calculation behave morally as a way to reduce social of economic valuation and the cost-benefit chaos and create peace." 34

Coal mining activity should give a Protection of access (conservation of access) to society, that aims to ensure each generation has the same level of intelligence as the level of utilization of the previous generation, while encouraging the improvement of the situation for each generation, its reflects the balanced allocation of rights and access to natural resources between different generations and among members of the current generation. Thus, protection of access provides equitable and non-discriminatory rights for every citizen of analysis (CBA) for environmental protection activities. Based on the CBA, a safeguard can be justified only if the safeguard's present benefit value is greater than or equal to the costs incurred for implementing the current safeguard. 37

Coal is the natural wealth contained in the bowels of the earth is a non-renewable natural resource. Therefore, its management needs to be done as optimally as possible by prioritizing the principles of efficiency, transparency, sustainability, and environmental insight and justice. 38 the current generation to use environmental of economic to state yet the risk distribution resources. However, in the use of these on coal mining activity among society, coal resources, each member of the current mining operator and state it can be concluded generation has an obligation (equitable that the existing environmental laws have not duties) to ensure that their actions will not and not being successful to provide the reduce future generations' access to these protection to all, as the nature of the resources. 35 The protection could be regulations solely tend to lead to conflicts. 39 described by making a law on the coal Every development implementation in coal mining which is regard to sustainable mining will always intersect with the development, community, economic and exploitation of natural resources. The environment protection. 36

Although the concept of intragenerational justice can be easily understood, in practice, it is complicated to implement. One practice that shows a deviation from

33 Gunawan, Y. (2021). Hukum Internasional: Sebuah Pendekatan Modern, Yogyakarta, LP3M UMY, p. 98 ${ }^{34}$ Stoker, K \& Stoker, M. (2012). The Paradox of Public Interest: How Serving Individual Superior Interests Fulfill Public Relations' Obligation to the Public Interest. Journal of Mass Media Ethics. 27. p 34.

35 Wibisana, A. G. (2017). Perlindungan Lingkungan Dalam Perspektif Keadilan Antar Generasi: Sebuah Penelusuran Teoritis Singkat. Masalah - Masalah Hukum. Vol. 46 No. 1. January. p. 9-19.

36 Gunawan, Y. (2014). Transboundary Haze

Pollution in the Perspective of International Law of State Responsibility. Jurnal Media Hukum. Vol. 21 No. 2 (2014). p. 170-180.

exploitation that is not appropriate often destroys natural resources, destruction of natural resources is defined as the unwise use of natural resources, and eventually, it will run out. 40 As the tide of chemicals born of the Industrial Age has arisen to engulf our environment, a drastic change has come about in the nature of the most serious public health problems. 41 Natural resource management should prioritize the public

37 Turner, R. K., Pearce, D. W. \& Bateman. I. (1993). Environmental Economics: An Elementary Introduction. Baltimore: Johns Hopkins University Press.

38 Azheri, B. (2016). Prinsip Pengelolaan Mineral dan Batu Bara. kajian Filosifis terhadap Undang Undang No 4 Tahun 2009. Jakarta: PT. Rajawali Pers.

${ }^{39}$ Muhdar, Et.al. Op.cit. (2020), p.663

40 Rahmadi, T. (2011). Hukum Lingkungan di Indonesia. Jakarta. RajaGrafindo Persada.

${ }^{41}$ Carson, R. 2002. Silent Spring. US: A Crest Book. 
interest, mere attention to the total wealth of Books and books chapter

society as goal of law and economics has resulted in negligence to proper wealth distribution. Meanwhile, any legal rule is influential in method of wealth distribution and law shall be formed in accordance with distributive consequences. ${ }^{42}$

\section{Conclusion}

Distributive justice in coal mining, it can be concluded that state have not success to give a fair distribution of justice among society, coal mining operator and state. Justice for one (intra) generation towards coal mining management through the existing environmental or mining laws have not success to provide the protection to society and the operators, coal mining activity solely tend to lead a conflicts in a society. The distribution of justice to the (one) intra generation have an uphill struggle and various obligations from each generation to ensure the protection of options, protection of environmental quality and protection of current generations access to natural resources. Economically, intra-generational justice must affect economic valuation of the benefits of environmental protection, Nevertheless, it can provide a fair distribution of benefits to the community, coal mining operators and state that considering that currently what is happening is that justice is not evenly distributed based on their achievements, where the community and the environment in the current generation is more likely to bear the risk of the impact of coal mining activities than to receive the benefits.

\section{References}

42 Bostani, M \& Malekpoor, A. (2021). "Critical Analysis of Kaldor-Hicks Efficiency Criterion with Respect to Moral Values. Social Policy Making and Incoherence". Advances in Environmental Biology. Vol 6 (7). p. 2036.

ApeldoornL. J. V. (1996). Pengantar Ilmu Hukum. Cetakan Ke Dua Puluh Enam. Jakarta: Pradnya Paramita.

Azheri, B. (2016). Prinsip Pengelolaan Mineral dan Batu Bara. kajian Filosifis terhadap Undang Undang No 4 Tahun 2009. Jakarta: PT. Rajawali Pers.

Carson, R. (2002). Silent Spring. US: A Crest Book.

Friedrich, C. J. (2004). Filsafat Hukum Perspektif Historis. Bandung: Nuansa dan Nusamedia.

Garner, B. A. (2009). Black Law Dictionary. 9th edition. U.S.A. Thompson West Group.

Gunawan, Y. (2021). Hukum Internasional: Sebuah Pendekatan Modern. Yogyakarta. LP3M UMY.

Nasution, B. J. (2014). Kajian Filosofis Tentang Konsep Keadilan dari Pemikiran Klasik Sampai Pemikiran Modern. Yustisia Vol. 3 (2) May August.

Rahmadi, T. (2011). Hukum Lingkungan di Indonesia. Jakarta. RajaGrafindo Persada.

Sands. P. (1995). Principles of International Environmental Law: Frameworks, Standards, and Implementation. Manchester: Manchester University Press.

Schlosberg, D. (2007). Defining Environmental Justice Theories, Movements, and Nature. USA: Oxford University Press.

Subhi, A. M. (2001). Filsafat Etika. Jakarta: PT. Serambi Ilmu Semesta.

Turner, R. K., Pearce, D. W. \& Bateman. I. (1993). Environmental Economics: An Elementary Introduction. Baltimore: Johns Hopkins University Press.

Wibisana, A. G. (2017). Keadilan Dalam Satu (Intra) Generasi: Sebuah Pengantar Berdasarkan Taksonomi Keadilan 
Lingkungan. Mimbar Hukum Vol. 29. (2). Helmi, M. (2015). Konsep Keadilan Dalam June. Filsafat Hukum dan Filsafat Hukum

Wibisana, A. G. (2017). Perlindungan Islam. Mazahib. Vol. 25. (2) December. Lingkungan Dalam Perspektif Keadilan Langhelle, O. (2000). Sustainable Antar Generasi: Sebuah Penelusuran Teoritis Singkat. Masalah - Masalah Hukum. Vol. 46 No. 1. January.

Yustika, A. E. (2013). Ekonomi Kelembagaan Development and Social Justice: Expanding the Rawlsian Framework of Global Justice. Environmental Values. Vol. 9 (3).

Paradigma. Teori. dan Kebijakan. Jakarta: Lestari, D. (2016). Dampak Investasi Sektor Erlangga. Pertambangan Terhadap Pertumbuhan Ekonomi Dan Tenaga Kerja. Jurnal Ekonomi. Manajemen dan Akuntansi. Vol.

\section{Journal article}

Adlhiyati, Z. \& Achmad. (2019). Melacak Keadilan dalam Regulasi Poligami: Kajian Filsafat Keadilan Aristoteles. Thomas Aquinas. dan John Rawls. Jurnal Hukum, Vol. 2 (2).

Amin, S. (2019). Keadilan Dalam Perspektif Filsafat Hukum Terhadap Masyarakat. El-Afkar Vol. 8 (1). January-June.

Awaliyah, S. (2014). Kontrak Karya Dan Perjanjian Karya Pengusahaan Pertambangan Batubara (KK/PKP2B). Jurnal Pendidikan Pancasila dan Kewarganegaraan. Vol. 27. (2).

Bostani, M, \& Malekpoor, A. (2021). Critical Analysis of Kaldor-Hicks Efficiency Criterion with Respect to Moral Values. Social Policy Making and Incoherence. Advances in Environmental Biology. Vol 6 (7).

Chambers, D. \& Guo, J-T. (2009). Natural Resources and Economic Growth: Some Theory and Evidence. Annals of Economics and Finance November.

Faiz, P. M. (2009). Teori Keadilan John Rawls Jurnal Konstitusi. Vol. 6 (1).

Gunawan, Y. (2014). Transboundary Haze Pollution in the Perspective of International Law of State Responsibility. Jurnal Media Hukum. Vol. 21, No. 2. December 16. (3).

Maryanto. (2018). Membangun Lingkungan Yang Berbasis Konsep Berkelanjutan. Jurnal Meta-Yuridis Vol.1 (1).

Morrice, E. \& Colagiuri, R. (2013). Coal mining, social, injustice and health: A universal conflict of power and priorities. Health \& Place 19.

Muhdar, M. (2020). Rekonstruksi Basis Perhitungan Kerugian Negara dalam Peristiwa Tindak Pidana Korupsi pada Sektor Sumber Daya Alam. Jurnal de Jure Vol 12 (1) April.

Muhdar, M. et al. (2015). Implikasi Hukum Terhadap Praktik Pinjam Pakai Kawasan Hutan untuk Kegiatan Pertambangan Batubara. Halrev. Vol 1(3).

Muhdar, M., Nasir, M. \& Nurdiana, J. (2020). Risk Distribution in Coal Mining: Fighting For Environmental Justice in East Kalimantan. Indonesia. Advances in Social Science. Education and Humanities Research. Vol. 499.

Nababan, R. K. (2017). Potensi PP KLHS dalam Mengintegrasikan Pembangunan Berkelanjutan dalam Penyusunan Kebijakan. Rencana. dan/atau Program. Jurnal Hukum Lingkungan Vol. 3 (2). March.

Qurbani, I. D. (2012). Politik Hukum Pengelolaan Minyak dan Gas Bumi di 
Indonesia. Jurnal Arena Hukum Vol. 6 (2). August.

Setyorini, S. N., Wirdyaningsih. \& Hazna, C. A. (2019). Wakaf Lingkungan Hidup dalam Rangka Pelaksanaan Pembangunan Berkelanjutan Dan Penegakkan Keadilan Antargenerasi. Journal of Islamic Law Studies Edition 9 May 2019.

Stoker, K. \& Stoker, M. (2012). The Paradox of Public Interest: How Serving Individual Superior Interests Fulfill Public Relations Obligation to the Public Interest. Journal of Mass Media Ethics. 27.

Tjakrawerdaja, S. (2008). Menunggu UU Induk Mengenai Perekonomian Nasional. Reform Review. Volume 2 (1) April-June.

Wowor, K. (2017). Penerapan Prinsip Berkelanjutan Sebagai Upaya Pencegahan Kerusakan Lingkungan Hidup Dibidang Pertambangan Ditinjau dari UU Nomor 4 Tahun 2009. Agri-Sosioekonomi Unsrat. Vol. 13 (2) July. 